\title{
The problem of goitre in Ceylon
}

\author{
BY K. MAHADEVA \\ Department of Nutrition
}

AND S. SENTHE SHANMUGANATHAN

Department of Biochemistry, Medical Research Institute, Colombo, Ceylon

\section{(Received 8 August 1966-Accepted 24 October 1966)}

\begin{abstract}
I. A survey of the incidence of goitre in Ceylon was carried out in the years $1947^{-9}$ and goitre was found to be endemic in the south-west sector of the Wet Zone of Ceylon.

2. In response to a request by the Ceylon Government to the World Health Organization for advice, Dr Dagmar Wilson in I 950 confirmed our earlier findings and as a short-term policy recommended the provision of iodine as KI tablets to the stress groups in the Wet Zone. This was initiated in August $195 \mathrm{I}$.

3. A second survey was carried out in $\mathrm{I}_{96} 6_{3}$ in nine of the villages in the Wet Zone that had been studied previously.

4. Statistical analysis showed that the incidence had significantly increased amongst the females in all nine villages and amongst the males in two villages.

5. A survey of the incidence amongst mothers attending antenatal clinics confirmed the existence of a strip of country where goitre was endemic.

6. The critical level of iodine intake from drinking water below which goitre becomes endemic has been shown to be ro $\mu \mathrm{g} / 1$.

7. The low iodine content of the water in the Wet Zone has been shown to be due to the persistent heavy rainfall, associated with high drainage into the ocean, by which the soil is leached.

8. The mean annual escape of water per square mile of a river basin (the yield factor) has been shown to be directly proportional to the intensity of endemic goitre in that basin.

9. The aetiological factors related to the problem of goitre are discussed. The prophylactic method failed as it was not sustained.

10. Iodization of kitchen salt is recommended for use by the general population. The amount of iodine added to the salt should not be great enough to produce any side-effects. Potassium iodate is suggested as the most suitable source of iodine for use in tropical regions with high humidity.
\end{abstract}

Greenwald (1953) has carried out research into the history of goitre in many countries and finds only four early references to the disease in Ceylon. His search among the available Western literature relating to Ceylon disclosed no mention of goitre during the Portuguese or Dutch periods. John Davy (I82I) after spending some 18 months in Ceylon, with three trips into the interior of the southern part of this Island, did not mention goitre although he devoted sixteen pages to the diseases of the Island. The earliest mention of goitre was by Bennett (1843) and Pridham (1849) in their description of Ceylon. They referred to the presence of goitre at Galle on the sea coast but did not refer to its presence elsewhere. Hirsch (1885) made a study of the geographical distribution of goitre and only referred to Galle. Ballou (1894) wrote of goitre being not uncommon among the native women in Galle. The Report of the Committee on Nutrition in the Colonial Empire (Economic Advisory Council, 1939) makes no mention of goitre in Ceylon, although the disease was noted as being present 
in other countries. Greenwald sums up by stating that goitre in Ceylon is a comparatively recent disease. He further adds that this fact is incompatible with the hypothesis that endemic goitre is due to a lack of iodine and to indicate that whatever effect the administration of iodine may have is not due to its making good a deficiency (Greenwald, 1946, 1950). The incidence is much more widespread now, extending beyond Galle in the Southern Province into the other provinces in the south-west sector of Ceylon. Greenwald appears not to have envisaged the possibility of an everrecurring leaching factor which could be continually in action depleting the iodine resources in the soils, and thereby the drinking water and food plants springing therefrom, thus making them iodine-deficient.

An island-wide survey of the incidence of goitre amongst the rural population of Ceylon was carried out by the Nutrition Department of the Medical Research Institute, Colombo, during the years 1947-9; goitre was found to be endemic in the south-west sector of Ceylon in the Wet Zone. As a result of this finding, the Government of Ceylon asked the World Health Organization for assistance in deciding whether goitre constituted a serious public health problem and, if so, to recommend appropriate prophylactic measures. In response to this request, Dr Dagmar C. Wilson of the WHO carried out a comparative survey of the occurrence of goitre among the schoolgoing population in ten different parts of the Island from February to March $195^{\circ}$ and confirmed our earlier findings (Wilson, 1954).

As a short-term policy, Wilson recommended for the stress groups in the Wet Zone, i.e. for pregnant women attending maternity clinics and for adolescent girls (from the sixth standard upwards) receiving school meals, the provision of iodine as potassium iodide in tablets each containing $5 \mathrm{mg}$ iodine $(6 \cdot 54 \mathrm{KI})$, one tablet to be administered once weekly.

This short-term policy was implemented by the then Director of Medical and Sanitary Services in August 195 I by a circular letter to all Government Medical Officers working in the Wet Zone. A repeat survey was carried out by the Nutrition Department of the Medical Research Institute in 1963 in nine of the previously surveyed villages in the Wet Zone, using the same methods as in 1947-9, with a view to evaluating the effect of the short-term policy and also to review the aetiological factors related to the problem. We are now reporting the results of the surveys in $1947^{-9}$ and 1963 .

\section{METHODS}

\section{Incidence of goitre}

Two independent surveys were done. The first was conducted by one of us (K. M.), with the help of two trained Nutrition Assistants and three Public Health Inspectors during the years $1947^{-9}$ when thirty-nine villages were selected at random all over Ceylon. All the residents of each village were examined for goitre by house-to-house visiting. Only those with a visible swelling in the region of the thyroid gland, which moved on deglutition when the head was held in the normal position and viewed from the front, were noted as positive. The subjects were not graded for size of goitre. The name, age, sex, presence of goitre. and period of residence in the area were recorded 
for each subject. If a person had goitre, his relationship to the other subjects with goitre in the same area was ascertained. When the areas with the highest incidence were found, other villages in the vicinity were surveyed in order to map out the endemic zone.

The second survey was carried out by the same team and the same methods in 1963 , I4 years after the prophylactic treatment recommended by Wilson in $195^{\circ}$ had been begun in nine of the villages that had been surveyed earlier in the endemic zone.

The incidence of goitre amongst pregnant mothers attending maternity clinics was ascertained from all the medical officers of health stationed throughout the Island. The criterion used for diagnosing goitre was the same as in the survey.

\section{Iodine content of drinking water}

In 1963 , during the second survey, the iodine content of the drinking water from all over the Island was estimated, by the modified method of Aceland (I957), by the Biochemistry Department of the Medical Research Institute.

Information on the mean annual escapes of water from the river basins was obtained and evaluated.

\section{RESULTS}

First survey

The thirty-nine villages surveyed in I947-9 are shown in Fig. $\mathrm{I}$ in relation to the provinces and the principal rivers. The incidence of goitre by province, village and sex is given in Table $\mathrm{I}$.

An endemic goitre belt was found to extend throughout the Western, Sabaragamuwa, Central, Southern and part of the Uva Province. The highest incidence $(3.3 \%)$ was in the Western Province between the river basins of the Kelani and Kalu Ganga. The incidence fades away towards the extremities of this belt into the other provinces. The endemic belt extends right to the sea in the Western and Southern Provinces: Pothupitiya in the Western Province and Uluvitike and Watareka in the Southern Province had incidences of $\mathrm{r} \cdot 5 \%, \mathrm{r} \cdot 6 \%$ and $\mathrm{r} \cdot 9 \%$ respectively.

Females were very much more affected than the males. The highest incidence for females was $6.6 \%$ at Wetera and for males it was $0.6 \%$ at Pelenwatte, an adjoining village. Both these villages are in the Western Province between the Kelani and the Kalu Ganga.

There was almost no goitre in the Northern, Eastern and North-western Provinces.

\section{Second survey}

The results of the survey in 1963 are given in Table 2 by village, sex and age-group.

Three age-groups were chosen, namely all ages, 17 years and above and the adolescent age-group 10-16 years. The incidence amongst females in six of the nine villages in the 17 years and above age-group was higher than in the 10-16-year agegroup. But amongst males the incidence in the 10-16-year age-group was higher, in five out of seven villages, than in the 17 years and above age-group. The two remaining villages had no goitre amongst males in the ro-16-year age-group. 
The incidence of goitre amongst males was small although no prophylactic treatment was given.

Four deaf mutes and three cretins were seen in this survey.
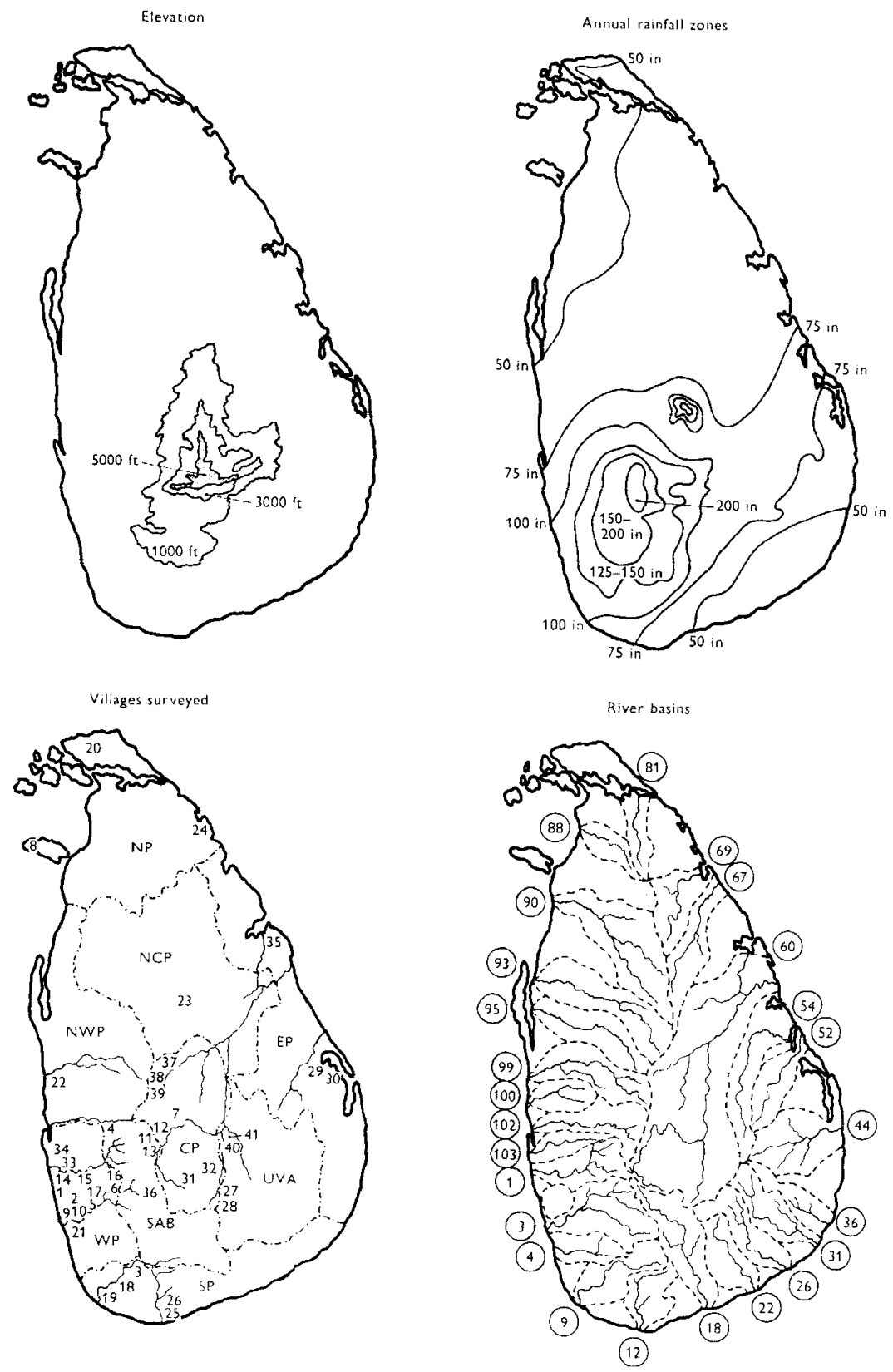

Fig. I. For legend see facing page. 


\section{Comparison of the two surveys}

A statistical analysis comparing the results of the first survey with those of the second after the prophylactic treatment showed (Table 3):

(I) The increase in the incidence of goitre getween $1947-9$ and 1963 was very highly significant at the $1 \%$ level for the entire population, for males and for females when all the villages were considered as a group.

(2) For all nine villages (separately), the incidence of goitre in females in 1963 was significantly higher at the $5 \%$ level than in $1947-9$.

(3) For seven villages (separately) the incidence of goitre in males in 1963 was not significantly higher at the $5 \%$ level than in $1947-9$. However, the increase for the other two villages-Gohagoda and Pothupitiya-was significantly higher at this level.

Table 4 gives the incidence amongst mothers attending maternity clinics throughout the island in 1963 . Goitre was found to be endemic in the Western, Sabaragamuwa, Central, Southern and Uva Provinces. This finding is similar to the finding in the first survey.

\section{Iodine content of drinking water}

Table 5 gives the iodine content of drinking water. Western Province had the lowest iodine content for Ceylon with a mean of $4.4 \mu \mathrm{g} / \mathrm{l}$, the values ranging from $2 \cdot 2$ to $10 \cdot 1 \mu \mathrm{g}$. The contents at the mouths of the two large rivers that drain the Western Province, the Kelani and the Kalu Ganga, were $3 \cdot \mathrm{I}$ and $2 \cdot 2 \mu \mathrm{g} / \mathrm{l}$. respectively. The Sabaragamuwa, Southern, North-western, Central and Uva Provinces all had mean contents of not more than $10 \mu \mathrm{g} / 1$; the values were $2 \cdot 5,4 \cdot 6,7 \cdot 5,8.7$ and $10 \cdot 0$ respectively. These provinces form the endemic goitre belt of Ceylon.

The iodine content of the water in the Eastern, North-central and Northern

Fig. I. Elevation, annual rainfall distribution, villages surveyed for goitre, and river basins in Ceylon. Three elevations, of $1000 \mathrm{ft}, 3000 \mathrm{ft}$, and $5000 \mathrm{ft}$, are shown. The rainfall zones are shown from 50 in./year up to 200 in. /year and above. Villages surveyed are shown in relation to the provinces and six of the major rivers. The numbers indicate the villages:

$\begin{array}{ll}\text { I Pelenwatte } & \text { I I Kirinde } \\ 2 \text { Wetera } & \text { 12 Udowita } \\ 3 \text { Udugama } & \text { I3 Kalugamuwa } \\ 4 \text { Talwatte } & \text { I4 Etul Kotte } \\ 5 \text { Bandaragama } & \text { I5 Buthgamuwa } \\ 6 \text { Ingiriya } & \text { I6 Bope } \\ 7 \text { Gohagoda } & \text { I7 Udumulla } \\ 8 \text { Talaimannar } & \text { I8 Uluwitike } \\ 9 \text { Pothupitiya } & \text { I9 Watareka } \\ \text { 10 Diyagama } & \text { 20 Tholpuram }\end{array}$

2I Koholana
22 Merawela
23 Padeniya
24 Mulliyawalai
25 Walgama
26 Hittetiya
27 Wiyadigune
28 Hingurugamuwa
29 Palaminmadu
30 Kalladi

3 I Blackpool

32 Kandapola

33 Hendala

34 Ragama

35 Muthur

36 Marapone

37 Harasgama

38 Aluvihare

39 Neluwa Kande

Provinces shown by abbreviations are:

$\begin{array}{llll}\text { NP Northern } & \text { NWP North-western } & \text { SP Southern } & \text { Sab P Sabaragamuwa } \\ \text { NCP North-central } & \text { CP Central } & \text { EP Eastern } & \text { Uva P Uva }\end{array}$

River basins are shown on an abbreviated hydrological map of the drainage basins of Ceylon (Irrigation Department, Ceylon, 1963, personal communication). The numbers indicate the river basins:

I Kelani Ganga

3 Kalu Ganga
9 Gin Ganga I2 Nilwala Ganga
I8 Walawe Ganga 102 Maha Oya
I03 Attangala Oya 
provinces which are all free from goitre was greater than in the other provinces; the values were $19.4,82 \cdot 8$ and $182 \cdot 8$ respectively. The critical level of the iodine content of drinking water may be said to be about $10 \mu \mathrm{g} / 1$.

Table I. First survey, 1947-9. Incidence of goitre in Ceylon by village, province and sex

\begin{tabular}{|c|c|}
\hline & Village \\
\hline $\begin{array}{l}\text { No. } \\
\text { in }\end{array}$ & \\
\hline Fig. I & Name \\
\hline I & Pelenwatte \\
\hline 2 & Wetera \\
\hline 5 & Bandaragama \\
\hline 6 & Ingiriya \\
\hline 9 & Pothupitiya \\
\hline 10 & Diyagama \\
\hline 14 & Etul Kotte \\
\hline I5 & Buthgamuwa \\
\hline 16 & Bope \\
\hline 17 & Udumulla \\
\hline $2 \mathrm{I}$ & Koholana \\
\hline 33 & Hendala \\
\hline 34 & Ragama \\
\hline 36 & Marapone \\
\hline 7 & Gohagoda \\
\hline I I & Kirinde \\
\hline 12 & Udowita \\
\hline 13 & Kalugamuwa \\
\hline 23 & Padeniya \\
\hline $3 \mathbf{I}$ & Blackpool \\
\hline 32 & Kandapola \\
\hline 37 & Harasgama \\
\hline 38 & Aluvihare \\
\hline 39 & Neluwakande \\
\hline 3 & Udugama \\
\hline I 8 & Uluvitike \\
\hline I9 & Watareka \\
\hline 25 & Walgama \\
\hline 26 & Hittetiya \\
\hline 27 & Wiyadigune \\
\hline 28 & Hingurugamuwa \\
\hline 8 & Talaimannar \\
\hline 20 & Tholpuram \\
\hline 24 & Mulliyawalai \\
\hline 29 & Palaminmadu \\
\hline 30 & Kalladi \\
\hline 35 & Muttur \\
\hline 4 & Talwatte \\
\hline 22 & Merawela \\
\hline
\end{tabular}

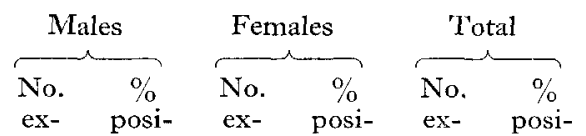

Province amined tive amined tive amined tive

\begin{tabular}{|c|c|c|c|c|c|c|}
\hline \multirow[t]{13}{*}{ Western } & 872 & 0.6 & 869 & $3 \cdot 2$ & $174 \mathrm{I}$ & $1 \cdot 9$ \\
\hline & 387 & 0.5 & $33^{6}$ & $6 \cdot 6$ & 723 & $3 \cdot 3$ \\
\hline & 646 & - & 659 & $3 \cdot 0$ & I 305 & I' 5 \\
\hline & 1513 & 0.3 & 1270 & $4 \cdot 3$ & 2783 & $2 \cdot I$ \\
\hline & I 437 & 0.2 & I 395 & $2 \cdot 8$ & 2832 & I'5 \\
\hline & 459 & 0.4 & 404 & $2 \cdot 2$ & $86_{3}$ & I'3 \\
\hline & I 492 & - & 1452 & $I \cdot 2$ & 2944 & 0. \\
\hline & 694 & - & $6 \mathrm{II}$ & $2 \cdot 3$ & r 305 & I. \\
\hline & 752 & - & 742 & $2 \cdot 0$ & I 494 & \\
\hline & 355 & - & $34 \mathrm{I}$ & $2 \cdot 4$ & 696 & \\
\hline & 276 & - & 283 & 0.4 & 559 & 0 \\
\hline & 1060 & - & 1159 & $I \cdot O$ & 2219 & 0. \\
\hline & 1321 & 0.2 & I 339 & $2 \cdot 4$ & 2660 & I. \\
\hline Sabaragamuwa & 480 & 0.2 & 453 & $5 \cdot 3$ & 933 & 2 \\
\hline \multirow[t]{10}{*}{ Central } & 614 & 0.2 & $5^{28}$ & $I \cdot O$ & I I 42 & \\
\hline & 429 & - & 459 & $I \cdot I$ & 888 & \\
\hline & 293 & 一 & 294 & - & 587 & - \\
\hline & 463 & - & 404 & 0.2 & 867 & 0 \\
\hline & 226 & $\cdots$ & I 55 & - & $3^{8} \mathrm{I}$ & - \\
\hline & 488 & 0.2 & 408 & $2 \cdot 0$ & 896 & I \\
\hline & 304 & 0.3 & 260 & $I \cdot 6$ & 564 & 0 \\
\hline & 791 & $0 \cdot 1$ & 794 & $5^{\circ} 0$ & I $5^{8} 5$ & \\
\hline & $37 \circ$ & 0.3 & $3^{6} \mathrm{I}$ & $5 \cdot 3$ & $73 \mathrm{I}$ & 2 \\
\hline & 105 & - & 125 & $I \cdot 6$ & 230 & 0 \\
\hline \multirow[t]{5}{*}{ Southern } & 524 & - & 507 & $1 \cdot 2$ & $103 x$ & 0 \\
\hline & 767 & $0 \cdot 3$ & 801 & $2 \cdot 9$ & ${ }_{15} 68$ & \\
\hline & 696 & 0.3 & 734 & 3.4 & 1430 & \\
\hline & I 399 & $O \cdot I$ & I 495 & 0.9 & 2894 & 0. \\
\hline & 531 & 一 & 525 & 0.8 & 1056 & 0. \\
\hline \multirow[t]{2}{*}{ Uva } & $45 \mathrm{I}$ & - & 406 & 0.5 & 857 & ० \\
\hline & 777 & - & 764 & 0.9 & I 54 I & 0 \\
\hline \multirow[t]{3}{*}{ Northern } & I 66 & - & 138 & - & 304 & - \\
\hline & 647 & -- & 598 & 0.3 & I 245 & \\
\hline & 398 & -- & 348 & 0.3 & 746 & 0 \\
\hline \multirow[t]{3}{*}{ Eastern } & I $8 \mathrm{I}$ & - & 148 & - & 329 & - \\
\hline & 1299 & - & 1192 & $O \cdot I$ & $249 \mathrm{I}$ & \\
\hline & I 315 & - & 1277 & -- & 2592 & 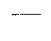 \\
\hline \multirow[t]{2}{*}{ North-western } & 235 & - & 237 & $\cdots \cdot \cdot$ & 472 & 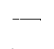 \\
\hline & 286 & - & 267 & - & 553 & \\
\hline
\end{tabular}

Annual escapes of water from river basins

The mean annual escapes from river basins all over Ceylon have been measured by the Irrigation Department at the river mouths and expressed as a unit called 'acre foot'. In this investigation the calculated escape per square mile of river basin has 


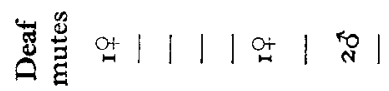

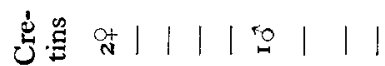

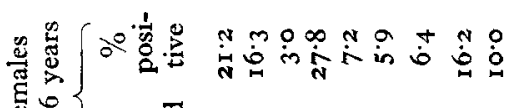

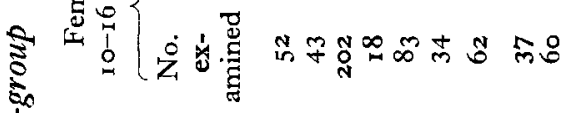

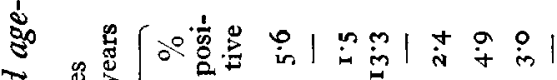

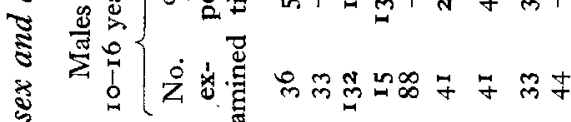
帘

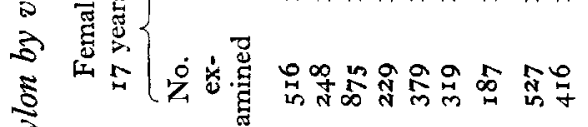
ปิ

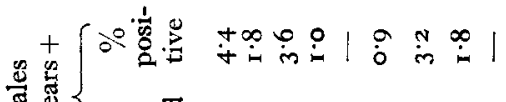

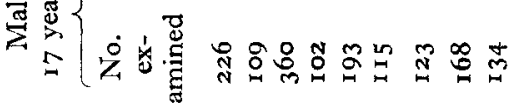

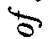

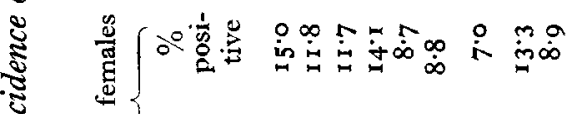

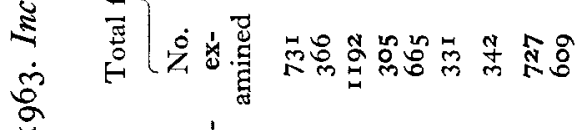

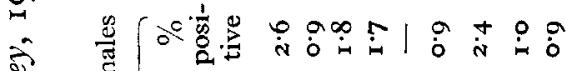
宽

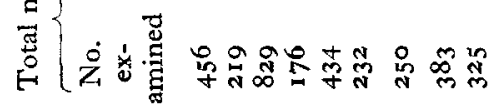
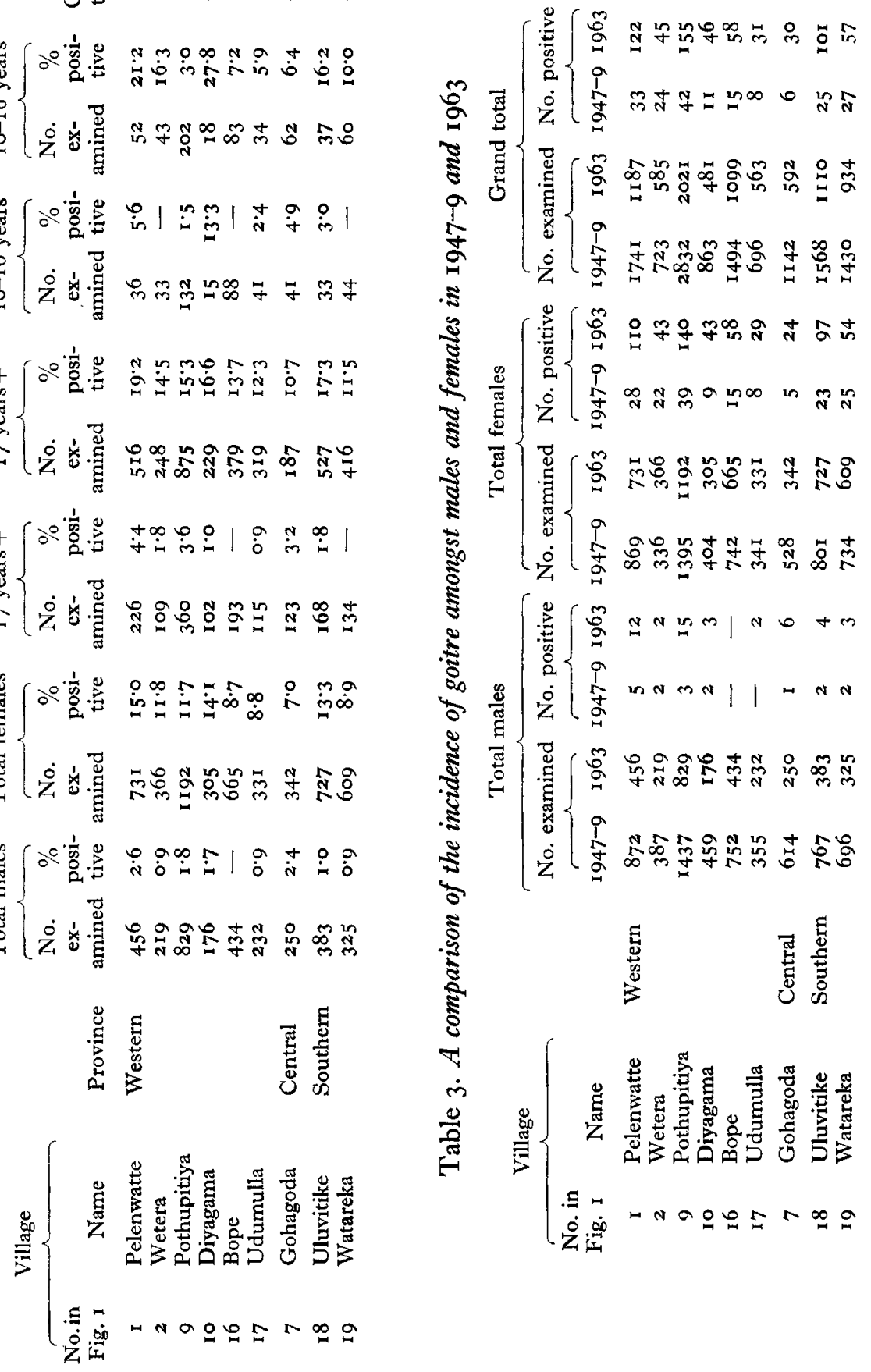

告 
been termed the 'yield factor'. The yield factors for the river basins in the south-west sector of the Wet Zone which is also the endemic area are above $\mathrm{r} \cdot \mathrm{O}$. The rivers in this area are the Kalu Ganga (3), Kelani Ganga (I), Gin Ganga (9), Nilwala Ganga (12), Maha Oya (102), Walawe Ganga (18) and the Attangala Oya (103), the corresponding yield factors being $5 \cdot 9,5 \cdot 3,4 \cdot 0,2 \cdot 7, \mathrm{I} \cdot 8, \mathrm{I} \cdot 2$ and $\mathrm{I} \cdot \mathrm{I}$ respectively. The figures in parentheses refer to river basins in Fig. I. The yield factors for the rivers in the dry zone (which are large in number) are $\mathrm{I} \cdot \mathrm{O}$ and below. The incidence of goitre in these river basins is nil.

\section{Table 4. Second survey, 1963. Goitre incidence of mothers at antenatal clinics in Ceylon}

\begin{tabular}{|c|c|c|c|c|}
\hline $\begin{array}{l}\text { Area of Medical } \\
\text { Officer of Health }\end{array}$ & Province & $\begin{array}{l}\text { No. seen } \\
\text { at clinics }\end{array}$ & $\begin{array}{l}\text { No. } \\
\text { positive }\end{array}$ & $\begin{array}{c}\% \\
\text { positive }\end{array}$ \\
\hline $\begin{array}{l}\text { Horana } \\
\text { Kalutara }\end{array}$ & Western & $\begin{array}{l}\text { I32 } \\
\text { I76 }\end{array}$ & $\begin{array}{l}46 \\
22\end{array}$ & $\begin{array}{l}34 \cdot 8 \\
12 \cdot 5\end{array}$ \\
\hline Kotte & & 186 & Io & 5.4 \\
\hline Homagama & & 294 & 12 & $4 \cdot I$ \\
\hline Padukka & & 277 & 4 & $\mathrm{I} \cdot 4$ \\
\hline $\begin{array}{l}\text { Warakapola } \\
\text { Dehiowita }\end{array}$ & Sabaragamuwa & $\begin{array}{l}224 \\
180\end{array}$ & $\begin{array}{l}53 \\
33\end{array}$ & $\begin{array}{l}23 \cdot 7 \\
18 \cdot 3\end{array}$ \\
\hline Ratnapura & & 415 & 53 & 12.8 \\
\hline Karawanella & & 168 & 13 & $7 \cdot 7$ \\
\hline Eheliyagoda & & 268 & 13 & $4 \cdot 8$ \\
\hline Balangoda & & 183 & I & 0.5 \\
\hline Kadugannawa & Central & $5^{64}$ & 14 & $2 \cdot 5$ \\
\hline Wattegama & & 176 & 4 & $2 \cdot 3$ \\
\hline Udugama & Southern & 28 & 5 & I7.9 \\
\hline Ambalangoda & & 187 & 4 & $2 \cdot \mathbf{I}$ \\
\hline Weligama & & 237 & i & 0.4 \\
\hline Tangalla & & 175 & - & - \\
\hline Badulla & Uva & 146 & 2 & $1 \cdot 4$ \\
\hline Koslanda & & 189 & $\mathbf{I}$ & 0.5 \\
\hline Mullaitivu & Northern & 62 & - & - \\
\hline Kopay & & 92 & - & - \\
\hline Killinochchi & & 38 & - & - \\
\hline Batticaloa & Eastern & $16 \mathrm{I}$ & - & - \\
\hline Valaichenai & & 94 & - & - \\
\hline Chilaw & North-western & I5 I & - & - \\
\hline Wariyapola & & 216 & - & - \\
\hline
\end{tabular}

Wherever possible yield factors have also been worked out at points in the higher reaches of rivers. The yield factors at these points in the rivers in the south-west sector are higher than $\mathrm{I}^{\circ} \mathrm{O}$, whereas the yield factor at similar points in rivers in the dry zone is below $1 \cdot 0$. In areas between the Kelani and Kalu Ganga, where the incidence of goitre is highest, the yield factors are also at their highest ranging from $2 \cdot 3$ to $8 \cdot 6$, thus showing that the incidence of goitre was directly proportional to the yield factor.

\section{Aetiological factors}

A large number of aetiological factors have been shown to be responsible for influencing the distribution of goitre in the different countries of the world (World Health Organization, 1960). A brief sketch of some of these factors as it affects the 
problem in Ceylon was thought useful for this paper at this juncture (Department of Census and Statistics, I962).

Topography. Ceylon is an island with an area of 25332 square miles. It comprises a mountainous area in the south-central region ranging in elevation from about 3000 to $7000 \mathrm{ft}$. This is surrounded by an upland belt of about 1000 $-3000 \mathrm{ft}$. The coastal plain occupies the rest of the island, being narrower in the west and south but broadening out in the east and north (see Fig. I).

Table 5. Iodine content of drinking water in Ceylon

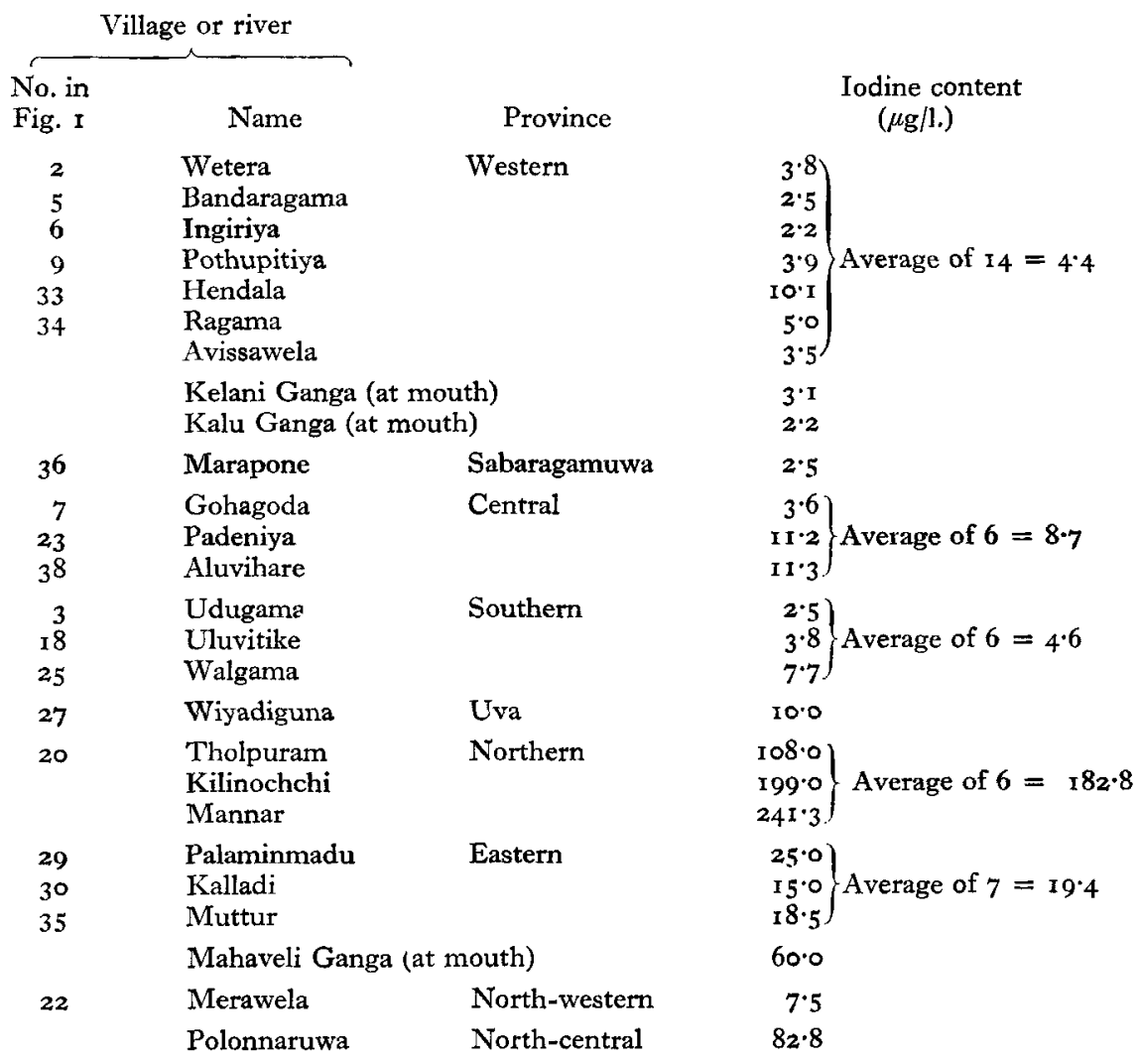

Climate. The climate of Ceylon is tropical. The annual average rainfall varies from about 40 in. in the driest zone, mainly in the north-west and south-east of the island, to over $200 \mathrm{in}$. at certain places on the south-western slopes of the hills. The mean annual rainfall in different parts is shown in Fig. I.

Rivers and waterways. The hydrographic picture of Ceylon with its central hilly mass takes on a radial pattern, the rivers flowing to the west, south and east being shorter than those flowing north, north-west or north-east on account of the lie of the land. The rivers and the river basins they drain are shown in Fig. 1 .

Geology. The geology of the land seems to have no bearing on the endemicity of goitre. 
Soils. The main soil groups of Ceylon have been recently classified (Moormann \& Panabokke, 196I). The soils of the endemic areas are mainly the red-yellow podzolic soils and to some extent the reddish brown lateritic soil overlying the Pre-Cambrian or Archaean rocks.

Other factors. Goitre in animals in Ceylon is very rare. The chief Government Veterinary Surgeon (personal communication) has not come across any case of goitre amongst cattle, buffalo, goats, pigs or dogs.

Rural water is generally soft and shows evidence of faecal contamination.

Dietary surveys have revealed the same pattern of food consumption throughout the island (Gunasekara, I958). As estimated from the recommended allowances suggested by Nicholls (195I), the calorie intake is slightly inadequate, the protein intake more so and the intakes of calcium, vitamin $\mathrm{A}$ and riboflavine are grossly inadequate. The goitrogenic group of vegetables, such as cabbage and knolkohl, is consumed by the rural population in almost negligible amounts ( $0.18 \mathrm{oz}$ per head per day).

\section{DISCUSSION}

The findings of the first survey in the years $1947-9$ and of the second survey in I 963 in the endemic areas 14 years after prophylactic treatment had been initiated show that there was a significant increase in the prevalence of goitre, more so amongst females.

In both surveys the total population was examined in randomly selected villages in rural areas as recommended by Perez, Scrimshaw \& Munoz (1960). The selected villages were representative of the area around them. Changes between the surveys in the numbers of people living in the villages were representative of the gradual migration, especially of men, from villages to towns in Ceylon; this has occurred at the same time as an increase in the birth rate. The same team carried out both surveys and the same methods were employed. The same nine villages were compared before and after prophylactic treatment.

In this investigation grading of the size of the goitre was thought not essential to determine whether goitre was endemic, although other workers thought it necessary (Perez et al. 1960). The suggested grading would need the services of full-time specially trained clinicians. Experience has shown that in the grading of the size of a thyroid into groups $O$ and $I$, the findings of two observers, or those of the same observer examining again the identical population, differ. The presence of a visible goitre, whatever its size, was taken as a criterion to determine whether goitre was endemic. Visible goitre falls into either group 2 or 3 of the classification recommended by Perez et al. (I960).

The endemic belt extends throughout the Western, Sabaragamuwa, Southern, Central and part of the Uva Province-the south-west sector of Ceylon. One of the factors that emerges from this investigation is that the very heavy rainfall followed by a high annual escape from the river basins into the ocean appears to deplete the soil of its soluble minerals. The low iodine content of the subsoil water of this area confirms this. The leaching of iodine is a continuous process, and the low iodine content in the 
subsoil water may therefore be reflected in the foodstuffs grown in these areas. The rural population living entirely on the produce of the land will be chiefly affected. The position is bound to deteriorate as the years go by. It is possible that the present increased prevalence of goitre is due to the depletion of iodine in foods to a critical level. The relative increase for the I4-year period may not be due only to the low intake of iodine. Other factors such as goitrogens or change of living conditions may be enhancing the effects of diets deficient in iodine. However, the dietary intake of goitrogenic foods, for example the Brassica group of vegetables, is almost negligible.

Greenwald (I950) has reported that in some countries goitre may practically disappear and then after many years reappear again with a high incidence.

Dr Wilson recommended the provision of $\mathrm{KI}$ tablets once a week to adolescent girls attending schools and to pregnant mothers attending clinics. Treatment began in August I95 $\mathrm{r}$, as a result of a circular to Government Medical Officers of Health and District Medical Officers doing health work in the endemic areas. These officers were asked to estimate their requirements and obtain supplies from a central depot-the Civil Medical Stores. Monthly returns were to be submitted. They were also requested to make a preliminary survey of schools and antenatal clinics at which the tablets were to be issued and thereafter annual surveys were to be conducted to evaluate the use of the drug as a prophylactic after a fair trial. Standards and methods of procedure were given. Notes on how to store the tablets were also included in the circular. It was estimated at that time that about $5 \frac{1}{2}$ million tablets were needed annually for this purpose, the cost being about Rs. 6670. The Iodine Educational Bureau consented to assist and the WHO gave a million tablets.

This scheme is a comprehensive one involving nearly a third of Ceylon. Inquiries during the second survey showed that the scheme started with a lot of enthusiasm, but with the passing of the years this enthusiasm waned. The prophylactic treatment has not been sustained continuously. Several factors contributed to this. There was no time limit stipulated for this short-term policy. Not all the adolescent girls attend school. In addition there are 3 months' holidays for schoolchildren every year during which the children would have had no treatment. The results of the treatment were not expected to be spectacular. What was hoped for was the prevention of a goitrefree people from developing goitre and a reversion of mild established goitre back to normality. This reversion may not have occurred in the more advanced cases amongst adolescent girls. In endemic areas it is known that goitre gets larger during successive pregnancies. Treatment at maternity clinics may also not have had any response. Complete reversion might have been expected in the population at large. This factor may have discouraged others from pursuing the therapy. Medical officers, as a rule, are transferred from area to area after a few years in a station. There is the possibility of the successor not continuing the prophylactic treatment. There is also the usual break-down in supplies due to administrative difficulties. No checks were carried out to determine whether there was any lowering of the iodine content of the pills during transport and storage, or from time of manufacture to time of field distribution.

The method of iodine supplementation adopted is quite valuable as a temporary measure in selected groups; as a permanent measure for the general population its 
usefulness depends upon the efficiency of the distributing system and the co-operation of the people, both of which are difficult to ensure at all times (Matovinovic \& Ramalingaswami, r960).

All the obstacles encountered in our investigation could be easily overcome if salt were iodized and the population were asked to use it. Salt is the most convenient vehicle through which iodine can be introduced into a diet. Iodization of salt could be carried out at levels that would not have side-effects on the population. Potassium iodate has been shown to be the most suitable source of iodine for use in tropical conditions with high humidity (Holman \& McCartney, 1960).

We are grateful for the statistical analysis to Mr L. S. Aponso, Medical Statistician, and to Mr D. A. Seneviratne and Mr D. D. Jayatilleke, Nutrition Assistants of the Nutrition Department, Medical Research Institute, for technical assistance in both surveys.

\section{REFERENCES}

Aceland, J. D. (1957). Biochem. F. 66, I77.

Ballou, M. M. (1894). Quoted by Greenwald, I. (1953). Ceylon med. F. 2, 140.

Bennett, J. W. (1843). Quoted by Greenwald, I. (1953). Ceylon med. F. 2, I40.

Davy, J. (1821). Quoted by Greenwald, I. (1953). Ceylon med. F. 2, I40.

Department of Census and Statistics (1962). Ceylon Year Book. Colombo: Government Press.

Economic Advisory Council (1939). Quoted by Greenwald, I. (1953). Ceylon med. 7. 2, 140.

Greenwald, I. (1946). f. clin. Endocr. 6, 708.

Greenwald, I. (1950). Trans. Am. Goiter Ass. p. 369.

Greenwald, I. (1953). Ceylon med. F. 2, 140.

Gunasekara, D. B. (r958). Ceylon $\mathscr{F}$. Sci. 9, 107.

Hirsch, A. (1885). Quoted by Greenwald, I. (r953). Ceylon med. F. 2, I40.

Holman, J. C. M. \& McCartney, W. (I96o). Monograph Ser. W.H.O. no. 44, p. 4I I.

Matovinovic, J. \& Ramalingaswami, V. (1960). Monograph Ser. W.H.O. no. 44, p. 385.

Moormann, F. R. \& Panabokke, C. R. (1961), Trop. Agric. II7, I.

Nicholls, L. (I95I). Tropical Nutrition and Dietetics, 3 rd ed. London: Baillière, Tindall and Cox. Perez, C., Scrimshaw, N. S. \& Munoz, J. A. (I960). Monograph Ser. W.H.O. no. 44, p. 369.

Pridham, C. (1849). Quoted by Greenwald, I. (1953). Ceylon med. F. 2, I40.

Wilson, D. C. (1954). Br. J. Nutr. 8, 90.

World Health Organization (1960). Monograph Ser. W.H.O. no. 44. 